\title{
Promoting European active citizenship: a participatory intervention towards the politicisation of youth social concerns
}

\author{
Joana P. Cruz*, Carla Malafaia*, Filipe Piedade*, \\ José Eduardo Silva**, Isabel Menezes ${ }^{* * *}$
}

[Ricevuto il 18 febbraio 2019

Accettato per la stampa il 26 aprile 2019]

\begin{abstract}
Despite their normative and regulatory nature, schools, as contexts for democratic education, are also places for free discussion, critical analysis and imagining personal and societal change. Under the European project $C A T C H$-EyoU, we developed a 2-years school-based intervention with a group of Portuguese secondary school students, inspired by the approach of youth participatory action research (YPAR). Having youths as co-researchers, both conventional (questionnaires and interviews) and emergent (theatre of the oppressed, photovoice) methods were mobilised to research dating violence, a problem previously identified by them as relevant in their community. The intervention process will be described, and its potential and limitations discussed.
\end{abstract}

Key words: youth, citizenship, participation, intervention, participatory research

Riassunto. Promuovere la cittadinanza europea attiva dei giovani: un intervento partecipativo sulla politicizzazione delle preoccupazioni sociali dei giovani

Le scuole come contesti di educazione democratica, nonostante la natura normativa, sono anche dei luoghi di discussione, analisi critica e di creazione di un cambiamento personale e societario. Nel progetto europeo CATCH-EyoU, abbiamo sviluppato un intervento a

* CIIE - Centro de Investigação e de Intervenção Educativas, Faculdade de Psicologia e de Ciências da Educação, Universidade do Porto, joanapmcruz@gmail.com; carlalmeida @fpce.up.pt; fpiedade@fpce.up.pt

** GIEP - Grupo de Investigação em Estudos Performativos, Centro de Estudos Humanísticos, Universidade do Minho, eduardosilva@gmail.com

${ }^{* * *}$ Faculdade de Psicologia e de Ciências da Educação, Universidade do Porto, imenezes @fpce.up.pt

Psicologia di Comunità (ISSN 1827-5249, ISSNe 1971-842X), 1, 2019

DOI: 10.3280/PSC2019-001006 
scuola della durata di due anni con un gruppo di studenti portoghesi della scuola secondaria, ispirato all'approccio della ricerca azione partecipata con i giovani (YPAR). Considerando $\mathrm{i}$ giovani come co-ricercatori, metodi convenzionali (questionari e interviste) ed emergenti (teatro dell'oppresso e photovoice) sono stati usati per indagare la violenza nelle relazioni tra pari, un problema precedentemente identificato dai giovani come rilevante nella propria comunità. L'articolo descrive il processo dell'intervento, e ne discute potenzialità e limiti.

Parole chiave: giovani, cittadinanza, partecipazione, intervento, ricerca partecipata

\section{Introduction}

Greta Thunberg, a 15-year-old Swedish student and climate-change activist, recently started a chain of school strikes that have spread through a number of countries, including Portugal, that concentrated thousands of students in 26 different cities on March 15, 2019. During an interview, and arguing that parents should support their children on striking, she stated that «Everyone keeps saying that the young people should be more active, and they're so lazy, but once we do something we get criticized». This kind of statement unveils the profound contradictions at stake in youth civic and political participation and the adult-centric visions of participation, which develop into narratives of youth apathy that, grounded on discourses of immaturity, fail to recognise youth's political agency (e.g., Quintelier, 2007; Menezes et al., 2012). Similarly, the role of schools in educating for participatory citizenship has gained momentum in the last few years, with critiques of the disproportionate focus on evaluation and concerns with labour market integration (Biesta, 2009; McCowan, 2009). Considering the centrality of school education in any democratic society, schools are a central context for youngsters' citizenship practices. However, is there room in schools to actually promote collective engagement and to value the students' own opinions and experiences in-and-outside of school? What are the limits of participatory interventions framed by the school?

Considering the importance of creating opportunities for youth participation in decision-making processes affecting their lives (Checkoway, 2011), as well as the predictive power of early political involvement later in life (Verba, Schlozman \& Brady, 1995; Zaff, Malunchuk \& Eccles, 2008), it is crucial to strengthen the link between citizenship and school education (McCowan, 2009). The participatory intervention presented in this article intended to instigate critical awareness and contribute to active citizenship, both local and European, bridging the school and community contexts

\footnotetext{
${ }^{1}$ Wearden, G. \& Carrington, D. (2019, January 24). Teenage activist takes School Strikes 4 Climate Action to Davos. The Guardian, Retrieved from https://www.theguardian.com/
} 
(Beane, 1990; McCowan, 2009). This intervention was triggered by a critical participatory learning model (cf. Finn, 1994), keeping in sight the importance of the "quality of participation experiences" in political development (Ferreira, Azevedo \& Menezes, 2012). Thus, the provision of opportunities for actual hands-on experiences (including people's own experiences) and critical analyses of power (considering the social and political structures of relevant problems) within a supportive environment for reflection and integration of the meanings of the experiences and activities, guided this school-based participatory intervention.

\subsection{Youth citizenship and political agency}

The period of adolescence is often regarded as a developmental phase characterised by a "time vacuum", in which individuals are seen for "what they are not" rather than for "what they [actually] are and what they [actually] do» (Augusto, 2008, p. 158). The notion of youth as in-between childhood and adulthood, «a period that is highly unstructured and unsettled [in industrialized societies]» (Arnett, 2006, p. 113), brings about important implications for youth's political capital (e.g., Hannon \& Tims, 2010). Indeed, young people's relationship with citizenship articulates with their future ownership of adult roles, linked to having a job, getting married and becoming a parent (Flanagan \& Levine, 2010; Hedkte, 2013). Regarded as "apathetic", "disconnected" and "disengaged" concerning civic and political issues, youngsters' voices are often dismissed and delegitimized (e.g. Delli Carpini, 2000; Zukin et al., 2006), while simultaneously being held responsible for the decline in participation in the political life (Andolina et al., 2002). On the other hand, research shows the limited outlooks provided by such generational interpretations of participation (e.g., Spannring, 2008), as there is actually evidence of Portuguese youth participating more than their adult counterparts (Magalhães \& Moral, 2008; Veiga, 2008). In this vein, Zukin and colleagues (2006, p. 189) state that considering youth as «apathetic and disengaged from civic life is simply wrong». Analysing youth participation necessarily involves the recognition of their heterogeneous, multiple and non-linear pathways (Pais, 2005), and their potential to introduce new possibilities and reinvent civic and political actions (Youniss et al., 2002; Norris, 2002). Taking Rancière's (2003) view on democracy, youths are already capable agents of democratic politics, and their becoming political subjects takes place through participation, adding new «ways of doing, of being and of saying» (Biesta, 2011, p. 150). In sum, a fair and inclusive debate about youth participation must begin by understanding "citizenship-as-practice", as opposed to 
"citizenship-as-acquisition" (Lawy \& Biesta, 2006), which entails the recognition of youth as ready to participate if spaces where democracy is lived and citizenship is practiced are provided, including in the school setting.

\subsection{Citizenship education at school}

Called on to revitalise civic and political participation, schools are required not only to promote school and community-based democratic experiences, but also to trigger critical awareness (Beane, 1990) towards an active citizenship (Kerr, 1999; Sarmento, 2004). However, when schoolbased citizenship education initiatives privilege knowledge and information about politics, their transformative potential is often reduced to rhetoric, in disregard of youths as "citizens of their own right» (Ribeiro, Caetano \& Menezes, 2016, p. 647). Such a scholastic model relates to Monteiro and Ferreira's (2011) metaphor of the school as a version of the curse of Midas, in which everything it «touches becomes school-like and it is not possible to add anything to the school that cannot be reduced to the school itself» (p. 6).

Understanding citizenship as a fundamentally contested concept requires understanding it as a sphere in which social change, plurality and contestation are part of its underlying democratic grammar of questioning the status quo (Freire, 1998; Mouffe, 2005; Shor, 1992). However, this is not necessarily the predominant perspective. The most recent Eurydice report (2017) defines citizenship education as follows:

«Citizenship education is a subject area which aims to promote harmonious coexistence and foster the mutually beneficial development of individuals and the communities in which they live. In democratic societies, citizenship education supports students in becoming active, informed and responsible citizens, who are willing and able to take responsibility for themselves and for their communities at the national, European and international level» (Eurydice Brief, 2017, p. 3).

While this definition of citizenship education highlights the importance of an active participation at the local, national, European and international levels, the focus on an "harmonious coexistence" and "mutually beneficial development" seems to neglect the central place of conflict in democracy (Mouffe, 2005). As stated by Zimenkova (2012, p. 48) «what is expected, then, from an active political citizen is that she maintains cohesion, observes politics and (if at all) critically reflects on politics». School curricula, in its turn, go in line with this regulatory understanding of citizenship education, either by presenting a one-sided, narrow version of what being a "good citi- 
zen" means (van der Ploeg \& Guérin, 2016) or by conveying mainly nonconfrontational perspectives, "with European citizenship being briefly and normatively presented to the students» (Piedade et al., 2018, p. 31).

\subsection{The potential of youth participatory action research in schools}

Participatory research processes have three distinctive key elements (Finn, 1994): 1) they are people-centred, grounded on the experiences and needs of participants and their communities, as the ongoing dialogue with community members enables participants to identify social issues collectively recognised as important; 2) they are developed based on a power sharing approach between facilitators and participants, embracing collaboration at the core of the process, aiming at the empowerment of students and their communities, regarded as producers of valid knowledge and involved in the exploration of the social and political roots of the issues at stake; 3 ) there is a close relationship between knowledge (critical discussion) and hands-on experiences (concrete actions).

Perceived as a critical methodology aimed at achieving social justice and the liberation of oppressed groups (Fals-Borda, 2001), participatory action research (PAR) comprises a range of collaborative methods and approaches (Banks et al., 2013). Kim (2016) traces the history of PAR considering its ontology, epistemology and methodology. Through engagement with a critical exploration of the communities they are involved with, supported by partnerships between researchers and participants, PAR projects aim at promoting empowerment and critical consciousness in their contexts (Reason, 2006). This revolves around the creation of a supportive and horizontal environment for exploring links between subjective and objective realities (Baum, MacDougall \& Smith, 2006), welcoming plural viewpoints and experiences, and offering room for a critical analysis of the social and political system (Fals-Borda, 2001) oriented to social change (Park, 1993). In this way, and considering the hierarchical (both structural and cognitive) features of the school setting, in participatory interventions the young students find themselves actively engaging in their education and in their community (McIntyre, 2006) - indeed, «emancipation is, every time and everywhere, actionable» (Hurtado, 2018, p. 4). The continuous circle of action and reflection is central to knowledge generation in PAR, sustained by the promotion of critical consciousness through the analysis of the factors (e.g., socioeconomic, political, cultural) influencing social and local problems; it is expected that this triggers mobilisation and action (Freire, 1998). Youth PAR usually involves training on research methods which are then 
used to identify social concerns in young people' schools and communities; to do so, young people become co-researchers of their surrounding reality and, thereafter, agents of change (Foster-Fishman et al., 2010; Ozer, Ritterman \& Wanis, 2010).

\section{Methodology}

\subsection{Aims and general description of the intervention}

The intervention described in this article, part of the European H2020 project $C A T C H$-EyoU, was guided by the following aims: a) to strengthen the youths' awareness of the EU and increase their interest and positive attitudes toward the EU; b) to enhance students' sense of ownership and competence in engaging with social and political issues that have a local as well as a European dimension; and c) to increase participants' awareness of their role as EU citizens, promoting their active social and political engagement at the local and European levels. The intervention was conducted throughout two school years, with a vocational class of grades 10/11 composed by 27 students, from a school in the north of Portugal. In the Portuguese case, the intervention was implemented by three researchers (members of the CATCH-EyoU team), likewise many YPAR projects that usually involve university researchers facilitating the process (McIntyre, 2006; Ozer, Ritterman \& Wanis, 2010). Thus, the researchers assumed the role of "initiators" - using Stoecker's terminology (2003), referring to triggering community involvement - aiming at a transformative research proposal (Nelson \& Prilleltensky, 2010). This was implemented in a fortnightly basis through 90 minutes sessions inserted in the students' timetable (occupying the slots of different classes), as the school considered that the intervention goals were related to learning objectives transversal to different subjects. The intervention followed fundamental guidelines developed by the CATCH-EyoU international team, and these steered the YPAR approach through different stages:

i) identifying and locating the problem: The first year was dedicated to the exploration of social issues perceived as relevant by the participants. Based on a collective exploration of students' perceptions and experiences, through artistic techniques, two issues were firstly identified as significant (power imbalances in the school and dating violence); eventually, dating violence was decided to be the focus of the research. Critical analysis of the social issues was also carried out throughout this phase. 
ii) mapping and understanding the social issue: The second year progressed based on the organisation of a more systematic research process, using conventional and non-conventional methods, seeking to better understand the problem with the school and the local community. By mapping social actors and institutions, and also by involving other students from the school, participants started their data collection process.

iii) suggesting solutions and actions: As the data collection was developed with a "problem solving" focus - from the identification of the roots of dating violence, to the social and political mechanisms that can address the problem at the local, national and European levels - the whole class brought to the fore some political actions. A number of them were suggested and, then, the list was narrowed down by considering their degree of feasibility and their European scope.

iv) sharing and disseminating recommendations: At the end of the intervention, students had the opportunity to present their recommendations to an audience of European policy-makers and academics, in Brussels.

\subsection{First year of the intervention - December 2016 to July 2017}

Recognizing that the arts could be central in a participatory intervention, and considering the experience of one of the researchers conducting the intervention, we used Arts-Based-Research (ABR) methodologies during the intervention process, including the Theatre of the Oppressed (TO). In line with the YPAR processes, we rested on the potential of artistic tools to engage and motivate youngsters, especially considering these particular students (from a vocational course that has a more flexible curricular structure and is less pressed by concerns with preparation for national exams) tend to resist formal instructional processes.

Based on Boal's methodology (2002), we began the intervention using different techniques that, by intentionally reconnecting the body and the mind, enabled body expression as a way of exposing and reflecting over daily settings.

First, body awareness was sought through a self-understanding that also helped to humanize the relationships inside the class. By observing oneself, the others and ourselves through the others, we tried to obtain reflective and conflictive opportunities to engage in a transformational process. Reflecting on the embodied dimensions of power was one of our major concerns: society is structured based on power inequalities, from where unjust and imbalanced relations emerge, that ought to be dismantled. As Nelson and Prilleltensky (2010, p. 304) put it: «the power to frame the issues, define the 
terms of the debate and set the agenda for discourse is to win the game before it happens».

Tab. 1 - Detailed description of year 1

\begin{tabular}{|c|c|c|c|}
\hline & $\begin{array}{c}\text { Phase 1 } \\
(\text { October - } \\
\text { December 2016) } \\
\end{array}$ & $\begin{array}{c}\text { Phase 2 } \\
\text { (December 2016 - March } \\
\text { 2017) } \\
\end{array}$ & $\begin{array}{c}\text { Phase 3 } \\
\text { (April - June 2017) }\end{array}$ \\
\hline $\begin{array}{l}\text { Main } \\
\text { Goals }\end{array}$ & $\begin{array}{l}\text { Project prepara- } \\
\text { tion: arrangements } \\
\text { with the school } \\
\text { board and prelimi- } \\
\text { nary mapping of } \\
\text { the community so- } \\
\text { cial structures }\end{array}$ & $\begin{array}{l}\text { Reflection on power dynamics; } \\
\text { Immersion in the Community; } \\
\text { Raising problems }\end{array}$ & $\begin{array}{l}\text { Critical analysis of the } \\
\text { problems }\end{array}$ \\
\hline Activities & $\begin{array}{l}\text {-Selection of class } \\
\text {-Establishment of } \\
\text { partnerships inside } \\
\text { and outside the } \\
\text { school communi- } \\
\text { ty. }\end{array}$ & $\begin{array}{l}\text {-Presentation of the project } \\
\text {-Exercises to unveil power re- } \\
\text { lations, for example, "The } \\
\text { great game of power" [A table, } \\
\text { three chairs and a glass of wa- } \\
\text { ter in the setting. The audience } \\
\text { is invited to debate power spa- } \\
\text { tial relations, associating lived } \\
\text { experiences to that particular } \\
\text { and imbalanced setting]. } \\
\text {-Identification and analysis of } \\
\text { social issues through TO tech- } \\
\text { niques, such as: } \\
\text { i) "Walk as if you were late to } \\
\text { school" [One had to walk in } \\
\text { different ways, remembering } \\
\text { daily situations in a conscious } \\
\text { form, and imitate others in } \\
\text { their walking patterns so they } \\
\text { could manage to see them- } \\
\text { selves through the others] } \\
\text { iii) "I've already" [All the stu- } \\
\text { dents sat on chairs arranged in } \\
\text { a circle, except one who stands } \\
\text { in the centre. He/she must state } \\
\text { a true event from his/her past } \\
\text { experience. Those who have } \\
\text { faced a similar event have to } \\
\text { stand up and quickly change } \\
\text { seats, so another person is } \\
\text { spotted in the centre, continu- } \\
\text { ing the revelations] }\end{array}$ & $\begin{array}{l}\text {-Problematization of } \\
\text { social issues, using } \\
\text { Image Theatre, news- } \\
\text { papers, music, specific } \\
\text { legislation and exer- } \\
\text { cises, such as the } \\
\text { "Rhythms Machine" } \\
\text { on Gender" [One by } \\
\text { one they had to create } \\
\text { a movement and a } \\
\text { sound they relate to a } \\
\text { given gender and en- } \\
\text { gage in a collective } \\
\text { machine with the } \\
\text { movements and sounds } \\
\text { of the others] } \\
\text {-Production of a video } \\
\text { to communicate the re- } \\
\text { flection about the so- } \\
\text { cial issues identified. }\end{array}$ \\
\hline
\end{tabular}




\begin{tabular}{|c|c|c|c|}
\hline Results & $\begin{array}{l}\text {-Preliminary context } \\
\text { evaluation } \\
\text {-Preparation of the } \\
\text { intervention }\end{array}$ & $\begin{array}{l}\text {-Self-implication } \\
\text {-Legitimation of the partici- } \\
\text { patory approach: seen as } \\
\text { "outside" the school authori- } \\
\text { tative model } \\
\text {-Identification of power rela- } \\
\text { tion in the school and dating } \\
\text { violence as significant social } \\
\text { issue } \\
\text {-Development of reflexive } \\
\text { and critical abilities as data } \\
\text { collection intersected with } \\
\text { data analysis. }\end{array}$ & $\begin{array}{l}\text {-Self-efficacy in partic- } \\
\text { ipating in political dis- } \\
\text { cussions } \\
\text {-Understanding the } \\
\text { commonality of the } \\
\text { problems } \\
\text {-Conscientization: } \\
\text { from immersive expe- } \\
\text { rience to emersion. }\end{array}$ \\
\hline
\end{tabular}

We reflected on the power dimension that exists in every social interaction - from the school's corridors to the director's office - and used Image Theatre as a way to problematize their views on different issues and their conceptualizations of "community". The "great game of power" was particularly useful to trigger specific topics that students felt were concurring to an oppression situation. In this sequence, two main issues emerged power imbalances in the school and dating violence. It was then decided, by majority, that dating violence would be the main focus, considering that it appeared to be a pressing issue within the group - some students were personally experiencing related problems - and also that it was a topic of interest in the school, where multiple projects were being developed. Then, several sessions were focused on gender imbalances, trying to uncover stereotypes (e.g. "Rhythms Machine"): and promote a critical analysis of the problem, in which Image Theatre was also fundamental.

\subsection{Second year of the intervention - September 2017 to July 2018}

Given the difficulties of working with an entire class of students, the facilitators decided to start the second year dividing it into four groups. These groups were encouraged to engage with specific research questions and methods in order to explore the problem of dating violence.

The researchers suggested four research methods, including more traditional and arts-based methods: Group A conducted interviews with a local police officer and a coordinator of an NGO to understand how different social agents tackle the problem of dating violence; Group B applied a survey to students from different school years in order to assess their attitudes toward different forms of dating violence (psychological, physical and sexu- 
al); Group C used photovoice to portray their own representations of violent relationships in order to explore the process of dating violence; and Group D engaged in image theatre (Boal, 2002) to investigate the factors triggering violent behaviours in dating relationships, through techniques aiming at body and dialogue exploration of different violent episodes they had experienced.

Tab. 2 - Detailed description of year 2

\begin{tabular}{|c|c|c|c|}
\hline & $\begin{array}{c}\text { Phase } 4 \\
\text { (October } 2017 \text { - March } \\
\text { 2018) } \\
\end{array}$ & $\begin{array}{c}\text { Phase 5 } \\
\text { (March 2018) }\end{array}$ & $\begin{array}{c}\text { Phase } 6 \\
\text { (April - July 2018) }\end{array}$ \\
\hline $\begin{array}{l}\text { Main } \\
\text { Goals }\end{array}$ & $\begin{array}{l}\text { Planning and conducting } \\
\text { the research }\end{array}$ & $\begin{array}{ll}\text { Sharing findings }- \text { lo- } \\
\text { cal dissemination } \\
\text { event }\end{array}$ & $\begin{array}{l}\text { Elaboration and } \\
\text { presentation of politi- } \\
\text { cal recommendations }\end{array}$ \\
\hline $\begin{array}{l}\text { Specific } \\
\text { Tasks }\end{array}$ & $\begin{array}{l}\text {-Defining research ques- } \\
\text { tions, participants and } \\
\text { methods: } \\
\text { i) What are the NGOs' and } \\
\text { police officers' answers to } \\
\text { the victims of dating vio- } \\
\text { lence? [interviews] } \\
\text { ii) How do students of dif- } \\
\text { ferent ages think about vi- } \\
\text { olence in dating relation- } \\
\text { ships? [questionnaires] } \\
\text { iii) In which ways do peo- } \\
\text { ple react towards represen- } \\
\text { tations of dating violence? } \\
\text { [photovoice] } \\
\text { iv) What are the factors } \\
\text { that trigger violent behav- } \\
\text { iour? [image theatre] } \\
\text { - data collection } \\
\text { - data analysis }\end{array}$ & $\begin{array}{l}\text { - Organising data for } \\
\text { documentation } \\
\text { - Collective definition } \\
\text { of the main results to } \\
\text { be presented and the } \\
\text { main implications } \\
\text { drawn from the re- } \\
\text { search } \\
\text { - Organisation of dif- } \\
\text { ferent formats of } \\
\text { communicating re- } \\
\text { search results } \\
\text { - Public presentations } \\
\text { in the dissemination } \\
\text { event }\end{array}$ & $\begin{array}{l}\text { - Cross-national re- } \\
\text { sults } \\
\text { - Elaboration of stu- } \\
\text { dent European pro- } \\
\text { posals }\end{array}$ \\
\hline $\begin{array}{l}\text { Outlined } \\
\text { Results }\end{array}$ & $\begin{array}{l}\text {-Knowledge acquisition of } \\
\text { how to outline and devel- } \\
\text { op a research process } \\
\text {-Capacity to analyse data, } \\
\text { collected through different } \\
\text { techniques, and extract } \\
\text { conclusions from it } \\
\text {-Ability to get a sense of } \\
\text { others experiences and } \\
\text { understand personal prob- } \\
\text { lems in a communitarian } \\
\text { and social frame }\end{array}$ & $\begin{array}{l}\text { - Enhance their sense } \\
\text { of self-efficacy } \\
\text { - Legitimize their role } \\
\text { as knowledge-makers } \\
\text { - Confrontation with } \\
\text { different opinions and } \\
\text { reformulation of the } \\
\text { analysis }\end{array}$ & $\begin{array}{l}\text {-Enhance their exter- } \\
\text { nal political efficacy } \\
\text {-Increase the under- } \\
\text { standing of the Euro- } \\
\text { pean dimension of } \\
\text { social problems and } \\
\text { how they are political }\end{array}$ \\
\hline
\end{tabular}


After data were collected, interpreted and discussed, the students were encouraged to turn their conclusions into political proposals at the local, national and European levels, and to make them public in dissemination events: one took place at the school and another at the Emilia Romagna Delegation to the European Union, in Brussels.

\subsection{Process monitoring}

In order to monitor the intervention, the facilitators conducted focus group discussions with the participating students in three moments ${ }^{2}$ : at the beginning of the intervention, at the end of the first year and at the end of the intervention. Focus groups sought to assess the students' expectations and motivations, promote a collective reflection about their experiences, and provide them room for suggesting ways to tackle possible frustrations throughout the process. This enabled incrementing the students' ownership of the decisionmaking processes, consolidating their roles as co-researchers. All focus groups were audio-recorded, transcribed and analysed, and some excerpts will be used below to illuminate the students' experiences in the intervention and, therefore, to discuss its potential and limitations in terms of enhancing youth political agency and citizenship. All participants' names are fictional.

\section{The process of politicisation driven by the intervention}

Dating violence, as many other social problems, is often framed as a personal problem, circumscribed to a private sphere, leaving untapped the processes and structures sustaining and reproducing its underlying inequalities. Considering that in order to clearly consider political phenomena one must remove him(her)self from them (Howe, Boal \& Soeiro, 2019), the use of TO was instrumental in promoting such a shift in perspective, with individuals being able to better understand their social place through the mirror of aesthetics, instigating awareness (Boal, 2002). Mainly throughout the first year, facilitators promoted the problematisation of dating violence through a process involving de-ideologization (Martin-Baró, 1985) and conscientization (Freire, 1983), by challenging the ruling ideological dis-

\footnotetext{
2 This research is part of the "CATCH-EyoU - Constructing AcTive CitizensHip with European Youth: Policies, Practices, Challenges and Solutions”, funded by European Union, Horizon 2020 Programme. Grant Agreement num. 649538; http://www.catcheyou.eu/. The data used for the analyses are accessible at the following link: http://doi.org/10.6092 /unibo/amsacta/6151
} 
course and activating the dynamics of de-alienation. This process was inherently a search for a solution with the students, departing from their perspectives to «overcome their alienated personal and social identities» (Jiménez-Domínguez, 2009, p. 38), which brought about a relevant transformation in the students' relationship with politics and citizenship. The idea of politics as a "boring" and distant matter was reconfigured during the two-year process:

«Jorge: I never thought of politics... but now... because of this project I have to think it through, isn't it? Based on what we've done... the problems we tried to solve - dating violence, gender inequality... all that is politics, isn't it?

Rafael: We discussed political topics.

Jorge: We debated. Discussing is making politics!

Diogo: Yes, we entered that world!» (09-07-2018).

Stepping into the "world of politics" was instigated by the personal implication in a concrete and collective problem raised by the group.

In fact, the sense of purpose driven by the willingness to change was pointed out as a fundamental difference between this project and regular school classes. Likewise, the fact that they were dealing with something that concerned them increased their sense of purpose and engagement.

Susana: «We investigate something that is totally present in our daily lives, but we didn't know it was so big!» (09-07-2018).

João: «Although it was tiring and hard-work, it was rewarding: we arrived at surprising findings, we discovered things we were not expecting / Luis: We got to outcomes that made us both happy and surprised!» (09-07-2018).

Students sometimes mentioned how the scholastic model often hinders their motivation to get engaged, mostly when such engagement is externally defined. According to Araújo and Monteiro (2018, p. 117) «to be a student is to work in and for the school»-, since both school attendance and employment imply external impositions and duties. In this intervention the aim was precisely to have students involved in activities and with topics meaningful to them. Consequently, the experience of actually playing an active role, as co-researchers, in exploring social issues through hand-on activities, made them enthusiastic.

Jéssica: «I like to participate in those activities because they give us more information than just talking about it. For example, the game of the chairs, the court activity, because they were more interactive... discussing only inside the classroom I think it would be more boring, and because this is active, people have more 
enthusiasm.»/ Ricardo: «And they remember more things.»/ Jéssica: «Yes, they have more ideas than if they were sat in class...» / Inês: «Getting out of our area. We are locked the whole day» (30-06-2017).

Although students' perceptions during the process were that they did not have the legitimacy to assume an "expert" position - and this seems to be a common feature of YPAR projects (e.g. Amsden \& VanWynsberghe, 2005) - this was softened by the end of the process when they found themselves presenting their results, which were recognised as added-value knowledge in the eyes of people they considered "relevant" others. The dissemination event that took place in their school played a major role in this regard. Diverse stakeholders attended it: the president of the youth chamber in the municipality, the director of the school, teachers, students, professionals working on gender violence and university researchers. The students got feedback on their work and watched their conclusions being brought to the table.

In addition, becoming "experts" on their own reality involved not only learning more about the issue at stake, but also taking the chance to voice concerns, acquiring the tools needed for that, and from an empowered position seeking to influence others and transform the status quo:

Isabel: «I have to be honest, right? I did not learn anything new about this subject in the project! Because I am a really melancholic person: I was already in such a situation [dating violence] so I knew what I was talking about in here. That's why I could take such good photos. But I liked to do this and take photos because I want the others to change their perceptions about this problem. And I know that what I did can help to clarify this issue. I did this to help the others. Because a person won't say "I need help" just like that, so I think photos can help transmit my message, what I felt in that position» (09-07-2018).

The «chance to voice their problems» implies the possibility of being heard by legitimate others. This was one of the foci of CATCH-EyoU: in the final phase of the intervention, students were called to reflect on legislative proposals that might transform their realities. Those proposals were presented at the Emilia Romagna Delegation to the European Union, in Brussels, where students participated in a public event together with other students from other European countries participating in the project. In the last focus group, they anticipated this meeting in Brussels in a very enthusiastic light:

José: «Youth can be listened to! I never thought we could be listened in relation to the EU. I thought we were too little to be considered!» (09-07-2018).

Maria: «If it were not for this project, I would never get in contact with EU» (09-07-2018). 
Surely, the dissemination events, both in Portugal - covered by two journal articles (a local newspaper and a widely read national newspaper) and in Brussels, were not only important to expand the impact of the intervention, by sharing the project and students' findings with a large audience, but also to give students a sense that they were being listened to. At the beginning of the intervention, students stressed the idea that young people really want «to be listened by someone who is willing to listen and capable of understanding!» (Renato). One of the positive outcomes of this project was precisely the decrease of the distance students felt towards institutional politics, due to the conditions and opportunities created for youngsters being listened to. This seems to have enhanced their feelings of political selfefficacy. Indeed, the increase in self-efficacy is one of the individual outcomes associated to YPAR projects (Ozer, Ritterman \& Wanis, 2010), with political self-efficacy being strongly related to diverse forms of participation (Klanderman, 1997; Barrett \& Zani, 2015). Based on their experience of engagement with a collective problem framed by a participatory intervention approach, students expressed their awareness and interest regarding social and political issues, displaying dispositions for future participation:

Luís: «I should be more aware of the things that are next to me, so I can help others!».

João: «We must be more aware of what is going on out there and if needed report the situation!».

Isabel: «I think it was a different experience because we could really be present and develop the whole process. It was not developed by others. It was us! We did everything ourselves!» (09-07-2018).

In this context, making sense of one's own experience, reinterpreted and enlightened by getting access to new information and knowledge, leads to re-signifying participation and, ultimately, to taking up the responsibility of «renewing a common world», which should be part of the role of contemporary education (Arendt, 1998, p. 196).

\section{And concluding}

De Groot and Veugelers (2015) defined the «a-political citizens [as] citizens who have not studied power inequalities and who have not been introduced to a school culture that teaches students how they can address social justice issues» (p. 28). This intervention aimed at the creation of a space, grounded in action, where the young students' agency was encouraged from the beginning, as they became part and parcel of the process it- 
self - with all the risks this entails (resistance and difficulties, but also possibilities). If, in order to be learned, democratic citizenship needs to be practiced (Lawy \& Biesta, 2006), it clearly opposes a scholastic ("static" and "abstract") type of citizenship (Pais, 2005). In fact, the contrast between the rationale of a participatory approach and the wider institutional context framing it, made visible some limits of this kind of intervention: i) the compulsory attendance exposed the paradox of participation (cf. Quaghebeur, Masschelein \& Nguyen, 2004); ii) the rigid hierarchical structure of the school, its division of time and roles, the circumscription to indoor activities, and the large number of students were difficult to accommodate; iii) the weight of school workload impacted on the students' participation, a problem reported in diverse YPAR projects (cf. Bostock \& Freeman, 2003; Cornwall \& Jewkes, 1995); iv) the students' embodiment of a somewhat normative school ethos (e.g., non-normative activities - such as theatre and photography - regarded as "less serious" and dismissed once they do "not count for evaluation"). Surely, any intervention of this kind demands systematic reflection from the facilitators in order to redirect the process, seeking the participants' engagement in activities that they may recognise as meaningful. This needs to be equated with the importance of mutual trust for successful outcomes in adult-youth partnerships and youthled research (Ford, Rasmus \& Allen, 2012), which requires a considerable amount of time (Kim, 2016). Aware of the challenges examined by Grant, Nelson \& Mitchell (2008), the facilitators tried to make the process flexible, allowing changes on planned activities to keep the students' motivation high, while not disregarding the guidelines of the larger European project this intervention was a part of. Even though the school board was very cooperative, keeping the students' engagement required time and energy from the facilitators in negotiating session slots on a weekly basis and in involving school teachers in the project, articulating it with some curricular activities. As Menezes stresses, «empowerment of people cannot be done without the empowerment of the professionals that interact with them» (2007, p. 112).

The possibility of implementing a school-based intervention such as the one presented here depended on multiple networks, in particular the network between universities, schools and community, which proved to potentiate quality experiences of participation. In fact, this intervention brought about several telling examples: the engagement of different teachers throughout the process, even when sporadic, helped them to rethink their role as educators in the school and broaden their ideas about their students (who showed to be capable of being active citizens); the inclusion of different community agents facilitated the establishment of a knowledge inter- 
face between different contexts; in the dissemination event, attended by multiple stakeholders, the youngsters' messages generated relevant mass media impact.

Going back to the initial example of the "Strike4Climate", one Australian student fighting in these climate protests stated in the streets of Canberra: «If so many students are skipping school, taking time out of their day to say something and try to make a difference, you should listen. Cause it definitely means that something's wrong and you need to act now» ${ }^{3}$. This piece expresses three things that come in line with our findings from this participatory research process: i) experiencing the world as an unjust place, students were willing to act upon it, and therefore should be included in collective transformational processes; ii) students identified problems that concerned them and were able to suggest changes, evidencing their ability to own political struggles; iii) students wanted to be listened to and have their suggestions taken into account for policy-making. For that, adults must be prone to hear their concerns, make their causes visible and force political changes, building community alliances with the youth (cf. Larson, Walker \& Pearce, 2005). The current challenge is then to see youth as citizens in the present here and now, and empowering them for social change, assuming them as stakeholders of the problems they live in (Gessner, 2017). This would mean the possibility to act, to make decisions, to question rules and have the opportunity to fortify their readings on power imbalances: "How classrooms are set up, who gets to talk when, how adults conduct themselves, how decisions are made, how lessons are enacted - all these (and more) inevitably serve as lessons in citizenship» (Westheimer, 2017, p. 17). So, it is crucial to reconsider how school is serving the purpose of rescuing students from apathy or, as Westheimer (2017) formulated: «What kind of citizen (is school forming)?».

By grounding itself in the reality of the communities, this space of dialogue struggled to transcend it, transforming individuals into agentic subjects and not mere spectators/observers of their own lives. So, now, the "participatory" ball is in our court: are we truly available to listen to students? And to commit ourselves to the changes they suggest? One of our students, when asked about his expectations about the project stated: «to be listened by someone who is willing to listen and capable of understanding». Are we listening? And are we capable of understanding?

\footnotetext{
${ }^{3}$ Hannah Higgins (2018, November 30). Thousands of students join climate protest. The Guardian, Retrieved from https://www.theguardian.com/
} 


\section{Acknowledgements}

The authors express their public recognition to the school Escola Secundária Dr. Joaquim Gomes Ferreira Alves and its board, particularly the director Dr. Álvaro Santos and president of the general council, Dr. Anabela Amaral, the class teachers and all the young people who participated in this project.

This research is part of the "CATCH-EyoU - Constructing AcTive CitizensHip with European Youth: Policies, Practices, Challenges and Solutions", funded by European Union, Horizon 2020 Programme. Grant Agreement num. 649538; http://www.catcheyou.eu/.

Joana P. Cruz and José Eduardo Silva are supported by the Portuguese Science and Technology Foundation (FCT) with a doctoral (PD/BD/114282/2016) and a post-doctoral (SFRH/BPD/100638/2014) scholarship, respectively. Carla Malafaia and Filipe Piedade were, at the time of this research, fellow researchers of the CATCH-EyoU project at the University of Porto.

\section{References}

Amsden, J., \& VanWynsberghe, R. (2005). Community mapping as a research tool with youth. Action Research, 3(4), 357-381. doi: 10.1177/1476750305058487

Andolina, M., Jenkins, K., Keeter, S., \& Zukin, C. (2002). Searching for the Meaning of Youth Civic Engagement: Notes From the Field. Applied Developmental Science, 6, 189-195. doi: 10.1207/S1532480XADS0604_5

Araújo, M.J. \& Monteiro, H. (2018). Crianças de todo o mundo, uni-vos! Notas sobre a submissão das crianças à "ideologia do trabalho útil". Ambiente \& Educação Revista de Educação Ambiental, 23(3), 170-188.

Arendt, H. (1968). Between past and future. New York: Penguin Books.

Arnett, J.J. (2007). Debate: Emerging Adulthood in Europe a Response to Bynner. Journal of Youth Studies, 9(1), 111-123. doi: 10.1080/13676260500523671

Augusto, N. (2008). A juventude e a(s) política(s): desinstitucionalização e individualização. Revista Crítica de Ciências Sociais, 81, 155-177.

Banks, S., Armstrong, A., Carter, K., Graham, H., Hayward, P., Henr, A., \& Strachan, A. (2013). Everyday ethics in community-based participatory research. Contemporary Social Science: Journal of the Academy of Social Sciences, 8(3), 1-15. doi: 10.1080/21582041.2013.769618

Barrett, M., \& Zani, B. (2015). Political and civic engagement: Multidisciplinary perspectives. London and New York: Routledge.

Barrett, M. \& Zani, B. (2015). Political and civic engagement: Theoretical understandings, evidence and policies. In M. Barrett \& B. Zani (Eds.), Political and Civic Engagement: Multidisciplinary Perspectives (pp. 3-25). London: Routledge.

Baum, F., MacDougall, C., \& Smith, D. (2006). Participatory action research. Journal of Epidemiology and Community Health, 60(10), 854-857. doi: 10.1136/jech.2004.028662

Beane, J.A. (1990). Affect in the curriculum: Toward democracy, dignity, and diversity. New York: Teachers College Press. 
Biesta, G. (2009). Good education in an age of measurement: On the need to reconnect with the question of purpose in education. Educational Assessment, Evaluation and Accountability, 21(1), 33-46. doi: 10.1007/s11092-008-9064-9.

Biesta, G. (2011). The Ignorant Citizen: Mouffe, Rancière, and the Subject of Democratic Education. Studies in Philosophy and Education, 30(2), 141-153.

Boal, A. (2002). Games for actors and non-actors. New York, USA: Routledge.

Bostock, J., \& Freeman, J. (2003). 'No limits': Doing participatory action research with young people in Northumberland. Journal of Community \& Applied Social Psychology, 13(6), 464-474. doi: 10.1002/casp.751

Checkoway, B. (2011). What is youth participation? Children and Youth Services Review, 33(2), 340-345. doi: 10.1016/j.childyouth.2010.09.017

Cornwall, A., \& Jewkes, R. (1995). What is participatory research? Social Science \& Medicine, 41(12), 1667-1676. doi: 10.1016/0277-9536(95)00127-S

De Groot, I. \& Veugelers, W. (2015). Why we need to question the democratic engagement of adolescents in Europe. Journal of Social Science Education, 14(4), 27-38.

Delli Carpini, M. (2000). Gen.Com: Youth, civic engagement, and the new information environment. Political Communication, 17(4), 341-349. doi: 10.1080/ 10584600050178942

European Commission (2017). Eurydice Brief: Citizenship Education at School in Europe (p. 3). Education, Audiovisual and Culture Executive Agency. Retrieved from https://www.na.org.mk/tl files/docs/eplus/eurydice/2018pub/ Brief CitizenshipEducation.en.pdf

Fals-Borda, O. (2001). Participatory (action) research in social theory: Origins and challenges. In P. Reason \& H. Bradbury (Eds.), Handbook of action research (pp. 27-37). London, UK: Sage.

Ferreira, P.D., Azevedo, C., \& Menezes, I. (2012). The developmental quality of participation experiences: Beyond the rhetoric that "participation is always good!". Journal of Adolescence, 35(3), 599-610. doi: 10.1016/j.adolescence. 2011.09.004

Finn, J.L. (1994). The promise of participatory research. Journal of Progressive Human Services, 5(2), 25-42. doi: 10.1300/J059v05n02_03

Flanagan, C. \& Levine, P. (2010). Civic engagement and the transition to adulthood. The Future of children, 20(1), 159-79. doi: 10.1353/foc.0.0043.

Foster-Fishman, P., Law, K., Lichty, L. \& Aoun, C. (2010). Youth ReACT for Social Change: A Method for Youth Participatory Action Research. American Journal Community Psychology, 46, 67-83. doi: 10.1007/s10464-010-9316-y

Ozer, E, Ritterman, M. \& Wanis, M. (2010). Participatory action research (PAR) in middle school: opportunities, constraints, and key processes. American Journal Community Psychology, 46(1-2), 152-66. doi: 10.1007/s10464-010-9335-8

Freire, P. (1983). Extensão ou comunicação? $7^{\mathrm{a}}$ ed. Rio de Janeiro: Paz e Terra.

Freire, P. (1998). Pedagogia do Oprimido. $25^{\text {a }}$ ed. (1 ${ }^{\mathrm{a}}$ edição: 1970). Rio de Janeiro: Paz e Terra.

Grant, J., Nelson, G., \& Mitchell, T. (2008). Negotiating the challenge of participatory action research: Relationships, power, participation, change and credibil- 
ity. In P. Reason \& H. Bradbury (Eds.), A SAGE handbook of action research: Participative inquiry and practice (2nd ed.) (pp. 580-60). London, UK: SAGE.

Gessner, S. (2017). Teaching Civic Education in a Migrating Global Community: How Can Students with a Migration Background Contribute to Didactics and Civic Education Theory? Journal of Social Science Education, 16(2), 41-51. doi: $10.2390 /$ jsse-v16-i2-1603

Hannon, C. \& Tims, C. (2010). An anatomy of youth. London: Demos.

Hedtke, R. (2013). Who is afraid of a non-conformist youth? The right to dissent and to not participate. In R. Hedtke \& T. Zimenkova (Eds.), Education for civic and political participation: A critical approach (pp. 54-78). New York, USA: Routledge.

Howe, K., Boal, J. \& Soeiro, J. (Eds.) (2019). The Routledge Companion to Theatre of the Oppressed. UK: Routledge.

Hurtado, J. C. (2018). Por uma infância emancipada? Caderno de Leituras n. 74 / Série Infância.

Jiménez-Domínguez, B. (2009). Ignacio Martín-Baró’s Social Psychology of Liberation: Situated Knowledge and Critical Commitment Against Objectivism. In M. Montero \& C. C. Sonn (Eds.), Psychology of Liberation, Peace Psychology Book Series, 37. Springer Science \& Business Media. doi: 10.1007/978-0-387-85784-8_3.

Kerr, D. (1999). Citizenship education in the curriculum: an international review. School Field, 10(3-4), 5-31. Tratto da http://www.ibe.unesco.org/fileadmin/ user_upload/Curriculum/SEEPDFs/kerr.pdf

Kim, J. (2016). Youth involvement in participatory action research (par): Challenges and barriers. Critical Social Work, 17(1). Tratto da http://www1. uwindsor.ca/criticalsocialwork/youth_involvement

Klandermans, B. (1997). The social psychology of protest. Oxford: Blackwell.

Larson, R., Walker, K., \& Pearce, N. (2005). A comparison of youth-driven and adult-driven youth programs: Balancing inputs from youth and adults. Journal of Community Psychology, 33(1), 57-74. doi: 10.1002/jcop.20035

Lawy, R. \& Biesta, G. (2006). Citizenship-as-practice: the educational implications of an inclusive and relational understanding of citizenship. British Journal of Educational Studies, 54(1), 34-50. doi: 10.1111/j.1467-8527.2006.00335.x

Magalhães, P. \& Moral, J.S. (2008). Os jovens e a política, Lisboa, Centro de Sondagens e Estudos de Opinião da Universidade Católica Portuguesa/cesop, 1-52. Tratto da https://jpn.up.pt/pdf/Os_jovens_e_a_politica.pdf

Martín-Baró, I. (1985). La desideologización como aporte de la psicología social al desarrollo de la democracia en Latinoamérica. Boletín de Avepso, VIII (3), 101108. Tratto da http://www.uca.edu.sv/coleccion-digital-IMB/wp-content/ uploads/2015/11/1985-La-desideologizacion-como-aporte-de-la-psicologiasocial-al-desarrollo-AVEPSO1985-8-3-3_9.pdf

McCowan, T. (2009). A 'seamless enactment' of citizenship education. Journal of Philosophy of Education, 43, 85-99. doi: 10.1111/j.1467-9752.2009.00669.x

McIntyre, A. (2006). Activist research and student agency in universities and urban communities. Urban Education, 41(6), 628-647. doi: 10.1177/0042085906292510

Menezes, I. (2007). Intervenção Comunitária - uma perspetiva psicológica. Porto: Livpsic/Legis Editora. 
Menezes, I., Cicognani, E., \& Amnå, E. (2019). CATCH-EyoU. Intervention in Schools. Methodology Evaluation and Main Results. EXTRACT Portugal. University of Bologna. http://doi.org/10.6092/unibo/amsacta/6151 [Dataset]

Menezes, I., Ribeiro, N., Fernandes-Jesus, M., Malafaia, C., \& Ferreira, P. (Eds.) (2012). Agência e participação cívica e política: Jovens e imigrantes na construção da democracia. Porto: Livpsic.

Monteiro, H. \& Ferreira, P. (2011). Unpolite Citizenship: The Non-Place of Conflict in Political Education. Journal of Social Science Education, 10, 5-11.

Mouffe, C. (2005). On the political. London: Routledge.

Nelson, G., \& Prilleltensky, I. (2010). Community psychology: In pursuit of liberation and well-being. New York: Palgrave MacMillan.

Norris, P. (2002). Democratic Phoenix: Reinventing political activism. Cambridge: Cambridge University Press.

Ozer, E., Ritterman, M., \& Wanis, M. (2010). Participatory action research (PAR) in middle school: opportunities, constraints, and key processes. American Journal of Community Psychology, 46(1-2), 152-66. doi: 10.1007/s10464-0109335-8

Pais, J. M. (2005). Jovens e cidadania. Sociologia, problemas e práticas, 49, 53-70. Tratto da http://www.scielo.mec.pt/scielo.php?script=sci_abstract\&pid=S0873$65292005000300004 \& \operatorname{lng}=\mathrm{pt} \& \mathrm{nrm}=\mathrm{i}$

Park, P. (1993). What is participatory research? A theoretical and methodological perspective. In P. Park, M. Brydon-Miller, B. Hall, \& T. Jackson (Eds.), Voices of change: Participatory research in the United States and Canada (pp. 1-19). Westport, CT: Bergin \& Garvey.

Piedade, F., Ribeiro, N., Loff, M., Neves, T. \& Menezes, I. (2018). Learning About the European Union in Times of Crisis: Portuguese Textbooks' Normative Visions of European Citizenship. Journal of Social Science Education, 17(2), 3140. http://www.jsse.org/index.php/jsse/article/view/873

Quaghebeur, K., Masschelein, J. \& Nguyen, H. (2004). Paradox of participation: giving or taking part? Journal of Community and Applied Social Psychology, 14, 154-165. doi: 10.1002/casp.776

Quintelier, E. (2007). Differences in political participation between young and old people. Contemporary Politics, 13, 165-180. doi: 10.1080/13569770701562658

Rancière, J. (2003). The philosopher and his poor. Durham, NC: Duke University Press.

Reason, P. (2006). Choice and quality in action research practice. Journal of Management Inquiry, 15(2), 187-203. doi: 10.1177/1056492606288074

Ribeiro, A.B., Caetano, A., \& Menezes, I. (2016). Citizenship education, educational policies and NGOs. British Educational Research Journal, 42,646-664. doi: 10.1002/berj.3228

Sarmento, M.J. (2004). As culturas da infância nas encruzilhadas da segunda modernidade. In M.J. Sarmento, A.B. Cerisara (Eds.) Crianças e miúdos: Perspetivas sociopedagógicas da infância e educação (pp. 9-34). Porto: Asa.

Shor, I. (1992). Empowering education: Critical teaching for social change. Chicago, IL: University of Chicago Press. 
Spannring, R. (2008). Understanding (non-) Participation: Forms, Meanings and Reasons. In R. Spannring, G. Ogris \& W. Gaiser (Eds.) Youth and Political Participation in Europe. Results of the Comparative Study EUYOUPART, pp. 55-85.

Stoecker, R. (2003). Community-based research: From practice to theory and back again. Michigan Journal of Community Service Learning, 9(2), 35-46. http://hdl.handle.net/2027/spo.3239521.0009.204

Van der Ploeg, P. \& Guérin, L. (2016). Questioning participation and solidarity as goals of citizenship education. Critical Review, 28(2), 248-264. doi: 10.1080/08913811.2016.1191191

Veiga, S. (2008). O impacto do envolvimento dos estudantes universitários em actividades extra-curriculares no empowerment psicológico e no desenvolvimento cognitivo-vocacional (Unpublished doctoral dissertation). University of Porto, Portugal.

Verba, S., Schlozman, K.L., \& Brady, H. (1995). Voice and equality: civic voluntarism in American politics. Cambridge, MA: Harvard University Press.

Westheimer, J. (2017). What kind of citizens do we need? Educational Leadership, 75(3): 12-18. Tratto da http://www.ascd.org/publications/educationalleadership/nov17/vol75/num03/What-Kind-of-Citizens-Do-We-

Need\%C2\%A2.aspx

Youniss, J., Bales, S., Christmas-Best, V., Diversi, M., McLaughlin, M. \& Silbereisen, R. (2002). Youth civic engagement in the twenty-first century. Journal of Research on Adolescence, 12(1), 121-148. doi: 10.1111/15327795.00027

Zaff, J., Malanchuk, O. \& Eccles, J.S. (2008). Predicting positive citizenship from adolescence to young adulthood: The effects of a civic context. Applied Developmental Science, 12(1), 38-53. doi: 10.1080/10888690801910567

Zimenkova, T. (2012). Active citizenship as harmonious co-existence? About the Political in Participatory Education. In R. Hedtke, T. Zimenkova (Eds.), Education for civic and political participation: A critical approach (pp. 36-53). New York: Routledge.

Zukin, C., Keeter, S., Andolina, M., Jenkins, K. \& Delli Carpini, M. (2006). A new engagement? Political participation, civic life, and the changing American citizen. Oxford: University Press. 